\title{
A DEEPER LOOK INTO RURAL ENGLISH TEACHERS' BELIEFS ABOUT ENGLISH
}

\author{
Nurun Hidayati \\ Sebelas Maret University \\ nurun.hidayati@gmail.com
}

\begin{abstract}
The research aimed at finding out two questions: 1). what are rural English teachers' beliefs about English in a rural school in facing the modern era?; and 2). to what extent is English important in a rural school related to its global role viewed from teachers' belief?. This paper utilized qualitative method in the form of case study. The respondents of the study were three English teachers from a rural school. The data were gathered through observation and interview then analyzed through the interactive model which consists of data reduction, data display, and conclusion: drawing/verification. The data analyzed reveals that: 1). English is crucially needed in rural school to develop human resources and to lead students to get the latest information; 2). English takes the global role in the rural school for helping students to learn internet and computer, to balance human resources and natural resources and as a foundation for making the connection with other people around the world in the wider scope. At the end of the paper, suggestions, and recommendation were also provided.
\end{abstract}

Keywords: teachers'beliefs, rural school, the importance of English

\begin{abstract}
Abstrak
Penelitian ini bertujuan untuk menjawab dua pertanyaan: 1). Apa saja kepercayaan guru Bahasa Inggris mengenai Bahasa Inggris dalam menghadapi era modern? dan 2). Dalam tatanan apa Bahasa Inggris itu penting disekolah pedesaan berkaitan dengan peran globalnya dilihat dari kepercayaan guru? Metode kulitatif dalam bentuk study kasus telah digunakan dalam penelitian ini. Responden penelitian ini adalah tiga guru Bahasa Inggris dari sebuah sekolah pedesaan. Data dikumpulkan menggunakan observasi dan wawancara lalu dianalisis menggunakan model interaktif yang terditi dari reduksi data, menunjukkan data, dan kesimpulan: penggambaran/verifikasi. Data yang dianalisis menunjukkan: 1). Bahasa Inggris sangat diperlukan di sekolah pedesaan untuk meningkatkan sumber daya manusia dan mengarahkan siswa untuk mendapatkan informasi terkini; 2). Bahasa Inggris berperan secara luas disekolah pedesaan untuk mempermudah siswa mempelajari computer dan internet, untuk menyeimbangkan sumber daya manusia dan sumber daya alam, serta sebagai dasar dalam berkomunikasi dengan orang-orang dari seluruh dunia dalam tatanan yang lebih luas. Di akhir tulisan ini, saran-saran dan rekomendasi juga dituliskan.
\end{abstract}

Kata Kunci: kepercayaan guru, sekolah pedesaan, pentingnya Bahasa Inggris 


\section{Introduction}

Investigating rural English teachers' beliefs about English in this modern era is a salient idea since English is considered a popular foreign language learned in Indonesia. As the result of primary observation, rural English teachers said there is no tourist who comes to the rural place as an interlocutor for students' real practice, nor a study tour to places where many English speakers live. Those phenomena caused students lack in English subject. In addition, English is not used as often as in the urban area. English is just seen as a compulsory subject that must be taught in the classroom. There is no follow up used in a real place with a real native English people except the English teacher in the classroom.

In addition, English teachers in Senior High School 1 Gangga, North Lombok, tend to see English just as a subject to be taught to fulfill their obligation. As long as the students can do the paper test, it is considered more than enough. It can be seen from the quantity of English teachers in that school and the lack of activity outside the classroom related to English subject. There is no English club or debate organization in this school. On the other hand, together with the unstoppable growth of information and technology, the beauty of a rural area is recently known in the more global world.

In 2015, Lombok accepted appreciations namely the World's Best Halal Honeymoon Destination and the World's Best Halal Tourism Destination, so does in 2016, Lombok gets more appreciations. The wealthy and the beauty of an area without the balance of its human quality will cause imbalance product which cannot be sustained in a long time. The hospitality of native people is needed in creating a good tourist destination. In addition, the ASEAN economic community, the interregional cooperation of the South East Asian nations forces Indonesia to be more global in the whole aspects such as education, technology, social, culture, and so on. This statement is in line with Crawford (2005) who says that one of the major results of globalization is the spread of English worldwide. In sum, the good human resources who expert in English are very needed in order to compete with other countries thus, in turn, Indonesia could be a producer, not just a consumer.

Related to those problems, the beliefs of rural English teachers in a rural school about English are challenging subject to be investigated since their roles affect their students' knowledge in English. In addition, English is considered as a worldwide language used in the whole aspects of modernity. It is caused by the power of its people specifically the power of its political and military since the British Empire (Cristal: 2003). In sum, this research is intended to answers these following questions: 1). what are rural English teachers' beliefs about English in a rural school in facing the modern era?; and 2). to what extent English is important in a rural school related to its global role viewed from teachers' belief.

\subsection{Literature Review}

\subsubsection{The notion of teachers' beliefs}

Belief is a complex terminology, it is a messy construct and it can be confusing under many aliases such as attitudes, values, judgment, perceptions, systems, personal theories, opinions, conceptions, internal mental process and some other terms (Pajares, 1992). Moreover, Pajares (1992) defines belief is not an objective fact but it is based on evaluation and judgment which are related to the overall aspect which taking the time to construct its meaning.

In addition, Borg (2001, p. 186) defined belief as "a proposition which may be consciously or unconsciously held, is evaluative in that it is accepted as true by the individual, and is therefore imbued with emotive commitment; further, it serves as a guide to thought and behavior". Borg states that the beliefs play a role as a basic guide for someone's 
behavior both consciously or unconsciously happen in their life. In addition, beliefs imbued the continuity action in doing something.

Both Pajares (1992) and Borg (2001) define belief as basic scaffolding which reflects the existing teachers' life. Teachers' beliefs related to the pedagogical action happened in teachers' life.

\subsubsection{The origin of teachers' beliefs}

The existing of teachers' beliefs may be influenced by some factors as Richards and Lockhart (1996) mention such as:

a. Teachers' own experience as language learners

Before doing a professional job as a teacher, someone has already met many teachers within their various characteristics and teaching styles. Moreover, there must be a friend of his/her styles who can achieve the best result in a given situation. This is in line with Perclova's (2006) statement that the everyday activity of teachers influences student's future when they teach which will appear in their own conceptions of teaching. In short, conscious or not, these experiences will affect the beliefs of teachers in their real practice.

b. Experience of what works best

In the real practice, there must be some failures and successful students in a given situation and of a specific material. As a teacher, that is a duty to reduce the failure and improve the succeed students as a goal of teaching and learning process. Within this condition, a teacher will explore ways to solve the challenges thus, in turn, the best solution will be found. This is also affecting teachers' beliefs as Woodcock (2011) states that teacher efficacy (the teachers' own effectiveness from their beliefs) is what behind the teachers' instructional decisions.

c. Established practice

In every school level, there must be a difference in the process of teaching, the bestestablished practice of it also affects the teachers' belief.

d. Personality factors

There must be a uniqueness of every teacher in teaching and learning process because it meets their personality. A discipline teacher will demand students to be a disciplined person regarding learning.

e. Educationally based or research based principles

There must be a principle which influences teacher in classroom activity which they got from the observation or the research that they have done. This is also affecting their beliefs.

f. Principles derived from an approach or method

Within years of teaching experience, a teacher may tend to apply one method or approach which they believe the most fruitful one because they know the advantages and the best practice of it together with the achievement of the students.

In addition, Borg (2003) uses teachers' cognition as a term to mention teachers' beliefs as stated in the teachers' beliefs model below: 


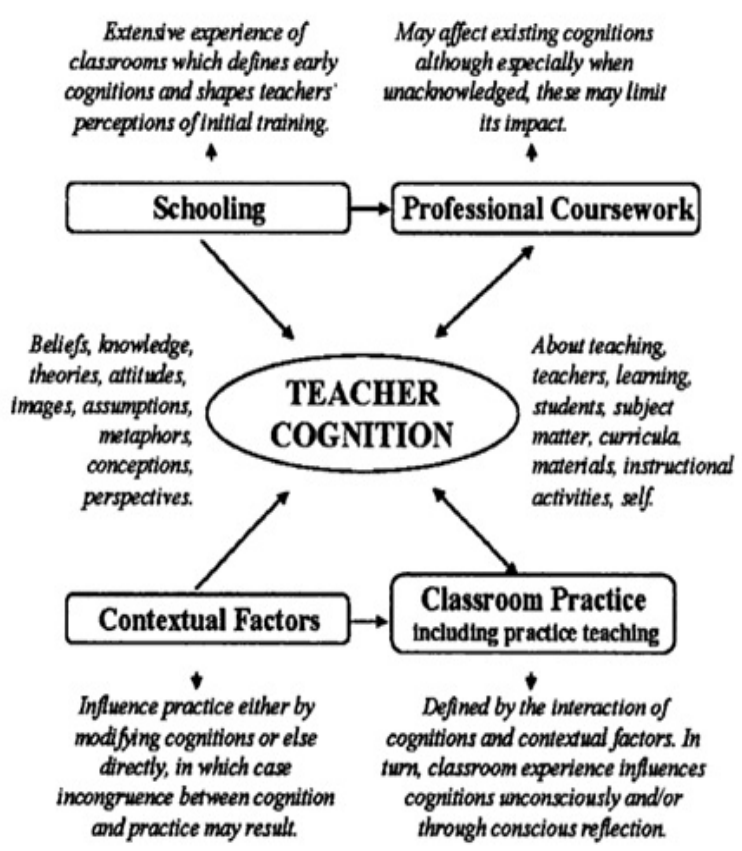

Image 1: Teachers' beliefs sources by Borg (2003)

In conclusion, as has been mentioned by Richards and Lockhart (1996) and Borg (2003) above, there are some factors affecting the existing of teachers' beliefs. One of them is the past experience of the teachers. The beliefs of an urban English teachers may be similar or different depending on the personality of the teachers itself which is affected by their beliefs. As the assumption of this research, the urban English teachers have different beliefs with the rural English teachers because of the different environment.

\subsubsection{Previous studies}

There is numerous research considered relevant to this current research. Zacharias (2003) conducted a survey research on teachers' beliefs about ELT in Indonesia regarding the role of English as a lingua franca. The finding reveals that almost all respondents saw English as a gate in getting better employment and higher social status. Zacharias (2003) also points out some problems of ELT in Indonesia such as inaccurate local-made material, the non-native speaker teachers, students' mother tongue, and the issues of culture. Due to overcoming those mentioned problems, cross cultural understanding (CCU) needs to be inserted while teaching English in ELT context. This previous study has the same purpose with the current research.

In 2009, Van Canh and Barnard conducted a research about teachers' beliefs in grammar teaching for Vietnamese EAP. The findings reveal that grammar is considered as a central feature of language crucial element in their teaching pedagogy. This study used survey study to know the teachers' belief about teaching grammar. This previous study surely differs from the current study in the term of nature of the research. In the same year, Moini (2009) also discussed teachers' cognition on teaching foreign language grammar. The finding reveals that teachers' personalities influence some aspects of their beliefs about grammar. This previous study also differs from the current study in the term of nature of the research

Cain (2012) studied the beliefs of primary teachers in Trinidad and Tobago about their practice teaching by using case study method. The findings reveal that the trainee's teachers 
need to be given the opportunity to develop and explore them self in finding the best way in teaching. On the other hand, this study did not shot the teachers' belief about English. Another related study may be conducted by Hassan (2013) about teachers' beliefs related to a grammar for the L2 classroom in its practice. The finding reveals that the way the teachers teach grammar in Lahore school, Pakistan, usually tradition but due to the needed, the teaching method is modified in some way. This previous study also differs from the current study in the term of nature of the research.

In line with Hassan (2013), Çapan (2014) also studied pre service EFL teachers' beliefs about grammar instruction at the university level. This research also used both qualitative and quantitative methodology and used interview, observation, and questionnaire to gather the data. The finding reveals that there is no change in their beliefs and in practice but it is in conscious knowledge. This previous work is also different from current study.

The newest previous study conducted by Larenas (2015) about EFL teachers' beliefs about teaching and learning in public education in Chilli. The case study method was used in this study. The finding reveals that teachers' beliefs take the role as the basis of their semantic memory which leads to their various fixed beliefs affecting by some aspects. This previous study might be relevant to the current study in the aspect of knowing EFL teachers' beliefs about EFL teaching and learning.

After looking at the previous studies above, the most common thing to research where teachers' beliefs about teaching in the field of grammar. Considering those research, this research is intended to analyze the teachers' beliefs about English as the subject taught regarding the more modern era in the rural school.

\section{Method}

The design of this research is qualitative in the form of case study. It is a study of an issue explored by one or more cases by using a bounded system (Creswell, 2007). It is used to gather the information about rural English teachers' beliefs about English in Senior High School 1 Gangga in this more modern era. The research took place in a rural school namely SMA 1 Gangga lies at Tanjung Bayan Street, Gangga Sub district, North Lombok, West Nusa Tenggara. This school is the only senior high school found in Gangga Sub district and this is the only public high school there. There are three major there those are science, social science, and language major. The participants of this study were the whole-three English teachers in that school.

The data sources of this research are divided into two parts those are participant and event. The participants are the English teachers in a school, SMA 1 Gangga. Meanwhile, the events are the way rural English teachers behave every day which determines their beliefs such as the way they dressed or talk or make a decision. The data were gathered through observation and interview. The observation used was participant observation while the interview used open ended interview but there was an interview guideline for storing a question first before conducting the interview.

The trustworthiness of this research used triangulation of data source and triangulation of data collecting method. The data sources triangulations are participant and events while the triangulations of data collecting method are observation and interview. Meanwhile, the model adopted for analyzing the data is the interactive model from Miles and Huberman (1994). The components of the interactive model itself are collecting the data, data reduction, data display, and the last is drawing the conclusion or verifying conclusion. 


\section{Findings and Discussion}

\subsection{Findings}

Regarding research questions, the findings of this study are discussed under this subcategories. According to the result of data collection, rural English teachers' beliefs about English reveals that English is crucial in that school to develop human resources and to lead students to get the latest information. In addition, English takes the global role in the rural school for helping students to learn internet and computer, to balance human resources and natural resources and a foundation in making the connection with the other people around the world in wider scope.

\subsection{Discussion}

The discussion of this study is under the following aspects: Rural English teachers' beliefs about English in a rural school and the important role of English in a rural school related to its global role viewed from teachers' belief.

\section{a. Teachers' beliefs about English in a rural school}

As everyone knows, English recently becomes more popular since it is needed in every aspect of life. If we want to be more global, English is the key to reach that dream. As the teachers of a rural school stated that "even our school lies in a rural place, but the importance of English is very crucial". It is proven by one of English teacher who continues her study. Even teaching, she is still continuing her study to master degree in the capital city of the island. She stated, "I personally love English and still studying it until today". Even in such a limited situation, she still pursues her study as she recognizes the importance of the subject she teaches.

Another thing the rural teachers stated about English is that "it can accelerate the technology transfer to develop an economy, technique, and political circumstances. Rural students need to know English not only to learn English itself but also to learn technology because computer and the internet use English in the instruction". Their view about English is linked to other aspects of life. This is how rural English teacher recognized the interdisciplinary skills of English and other subjects. In addition, another teacher said, "English is spoken by many people, if we want to have the more global association, and mastering English is one of the keys". This indicates how they realize the importance of English in this era.

To sum, even in rural school, English teachers' beliefs about English reveal that they recognize the crucial role of English both for their career and their students' future career to compete in the future.

\section{b. The Importance of English in a Rural School Related to its Global Role Viewed from Teachers' Belief}

Regarding the importance of English in a rural school, teachers reveal some facts that English important in developing human resources. The natural resource in the rural area is huge and rich since you can find many useful plantations in the rural area. Besides, the natural resource is one of the biggest incomes of people living in rural area. If human resources in the rural area understand English, they can sell their plantations to more global market, such as abroad market. Imagine how rich they will be. However, the current condition of human resources in the rural area is too far from modernization.

Moreover, one of the teachers stated: "English has great influence in Anglo Saxon culture and until now, it still has great influence even from a rural school which is far from 
Europe". Even the distance between the origin of English and the setting of this study is considered too far, English is still popular. In summary, the rural school needs English as a method of balancing the natural resources and human resources within its culture and its role in this modern era.

Furthermore, the global role of English in a rural school related to the other aspects of life such as the economy, tourism, politics, and modernization. All teachers tend to say almost the same things when they asked about the global role of English in a rural school "Even from rural school, if we want to compete in the wider area, English must be mastered first", "as long as English is mastered, whenever you go, you can survive with your knowledge in English skills". Related to the era of technology, English also takes a global role to make easier in learning and applying the technology both for life and learning.

Regarding above-mentioned reasons, the good natural resource without good human resources is not enough. in getting the best natural resources' care, the human resources are also needed to be increased. Almost all of the beliefs of English teachers in rural school taken from their experience as Richards and Lockhart (1996) and Borg (2003) mentions that experience also affects teachers' beliefs about English. In short, English takes a basic role which influences other aspects of life to be more success or vice versa.

\subsection{Limitation}

Since the notion of teachers beliefs' is too wide topic discuss, this current research just focuses on the point of view of a English teachers about English in the rural school.

\section{Conclusion}

\subsection{Conclusion}

After having explained the role of English in a rural school, some points can be concluded that: 1). Rural English teachers' beliefs consider English is very important in rural school to develop human resources and to lead students to get the latest information. That belief is drawn from their experience in their society regarding the need of English in this modern era. 2). English takes a very crucial role in the rural school to balance the role of natural resources and human resources. Besides, the global roles of English in rural school can be seen in its influence in the technology and its influence in connecting people around the world.

\subsection{Suggestion}

There are some points that teachers need to consider: 1).English teachers should deliver not only the knowledge and skill to their students but they also have to make students realize how important English is in this era whenever they are. 2). English teachers should develop not only skills and knowledge of English but also their cultural awareness as the supplies for their students in their future career.

\subsection{Recommendation}

Based on the result of the study, the deeper investigation about English teaching from English teachers point of view needs to be conducted in further research. It needs to be considered since one of the criteria for the success of English teaching is based on teachers' beliefs. 


\section{References}

Borg, M. (2001). Key Concept in ELT: Teachers' Beliefs. ELT Journal. Vol. 55/2. Oxford University Press. pp. 186-187

Cain, M. (2012). Beliefs about Classroom Practice: A Study of Primary Teacher Trainees in Trinidad and Tobago. International Journal of Humanities and Social Science, Vol. 2 No. 3, pp.96-105

Çapan, S. (2014). Pre-Service English as a Foreign Language Teachers' Belief Development about Grammar Instruction. Australian Journal of Teacher Education, 39(12). pp. 131152 available at http://dx.doi.org/10.14221/ajte.2014v39n12.9

Crawford, J.C. (2005) English as a lingua franca: Implications for teacher education programs. In Proceedings, 22nd International Conference on English Teaching and Learning in the Republic of China, pages pp. 77-87, National Taiwan Normal University, Taipei, Taiwan.

Creswell, J.W. (2007). Qualitative Inquiry and Research Design, Choosing among five approaches; Second Edition. London: Sage Publications

Crystal, D. (2003). English as a Global Language; Second Edition. London: Cambridge University Press

Hassan, N.H. (2013). The Impact of Teachers' Beliefs on L2 Grammar Teaching - M.A. Dissertation. Language in India www.languageinindia.com

Larenas, C.D. (2015). A Case Study on EFL Teachers' Beliefs About the Teaching and Learning of English in Public Education*. Porta Linguarum 2,.pp. 171-186.

Miles, M.B, \& Huberman, M. (1994). Qualitative Data Analysis: A Sourcebook of Methods. London: Sage Publications

Moini, M.R. (2009). The impact of EFL teachers' cognition on teaching foreign language grammar. Pazhuhesh-e Zabanha-ye Khareji, No. 49, Special Issue, English, pp. 141-164. University of Kashan, I.R. Iran

Pajares, M.F. (1992). Teachers' Beliefs and Educational Research: Cleaning Up a Messy Construct. Review of Educational Research. Vol. 62, No. 3, pp. 307-332

Perclová, R. (2006). The implementation of European Language Portfolio pedagogy in Czech primary and lower-secondary schools: beliefs and attitudes of pilot teachers and learners. Finland: the University of Joensuu, Faculty of Education

Ridcard, C.J. \& Lockhart, C. (1996). Reflective Teaching in Second Language Classrooms. Cambridge: Cambridge University Press

Van Canh, L. \& Barnard R. (2009). A survey of Vietnamese EAP Teachers' Beliefs about Grammar Teaching. Englishes and Literatures-in-English in a Globalised World: Proceedings of the 13th International Conference on English in Southeast Asia (pp. 246259). Singapore: National Institute of Education, Nanyang Technological University.

Woodcock, S. (2011)."A cross sectional study of pre-service teacher efficacy throughout the training years.," Australian Journal of Teacher Education: Vol. 36: Iss. 10, Article 2. pp. 23-34 Available at http://ro.ecu.edu.au/ajte/vol36/iss10/2

Zacharias, N.T. (2003). A survey of tertiary teachers' beliefs about English Language Teaching in Indonesia with regard to the role of English as a global language. Institute for English Language Education: Assumption University of Thailand. ASIA EFL Journal MA-ELT THESIS. Available in: http://asian-efl-journal.com/thesis_N_Zacharias.pdf. 